\title{
The Influence of Airline Brand on Purchase Intention of Air Tickets in China
}

\author{
Pilsung Choe* \\ Department of Industrial Engineering, Tsinghua University, Beijing, China \\ Yi Zhao \\ Department of Statistical Science, Cornell University, Ithaca, NY, USA
}

(Received: December 20, 2012 / Revised: March 6; May 24; May 30, 2013 / Accepted May 31, 2013)

\begin{abstract}
The number of airline passengers in China has rapidly increased, so understanding the relationship between brand equity of airlines in China and ticket purchase intention of Chinese passengers is important for airline business success in China. Using the structural equation modeling, this study explores the relationships among determinants of brand equity as well as the relationships between brand equity, transition cost, and purchase intention. The major findings are: brand equity of airlines directly influences purchase intention; transition cost directly influences brand equity; and transition cost indirectly influences purchase intention in China. In addition, the results show that marketing strategies using the airline brand can be more effective for certain customer groups, including high income customers, married customers, government servants, and businessmen.
\end{abstract}

Keywords: Airline Brand, Structural Equation Modeling, Brand Equity, China, Purchase Intention, Brand Marketing

* Corresponding Author, E-mail: pschoe@gmail.com, pchoe@tsinghua.edu.cn

\section{INTRODUCTION}

A brand is a name, symbol, or logo to distinguish a product from other products, and it also refers to a certain feature of a product creating awareness, reputation, and prominence of the product in the market (Keller, 2012). The brand has been an important criterion for consumers' purchase in many countries, but less attention has been paid to Chinese consumers in the past. But, now in China, brand extension is becoming an important marketing activity for business success due to the rapid and sustained economic growth.

The latter trend applies to most industries in China, especially to airline industry as the volume of airline passengers in China has increased dramatically. The National Bureau of Statistics of China (http://www.stats. gov.cn) indicates that China had around 290 million airline passengers in 2011 with a $9.2 \%$ growth rate compared to 2010. Along with this rapid growth of airline passengers, Civil Aviation Administration of China (http:// www.caac.gov.cn/H1/H2/200808/t20080828_18587.html) specifies the brand as one of the important factors affecting the passenger's choice of a Chinese airline. These factors include safety, departure time, service, price, punctuality, plane type, and frequent flyer program as well as brand.

Although extensive research has been made on brand, most of the research focuses on certain fields of industries such as hotel, restaurant, electronic appliance, clothes, and automobiles (Aaker, 1996; Hu et al., 2004; Hwang and Kandampully, 2012; Keller, 1993; Kim and Kim, 2004; Pappu, 2005; Tolba and Hassan, 2009), whereas research on airline brand is rare. Most research on airlines has been about airline services (Aksoy et al., 2003; Ostrowski et al., 1993; Park et al., 2004; Sultan and Simpson, 2000). Chinese airline brand, in particular, has not been studied yet at any respect. As aforementioned, considering the rapid growth of the number of 
airline passengers and the importance of brand extension in China, research on Chinese customer behavior toward airline brands is expected to provide practical answers and solutions to the airline marketers in China.

It is widely accepted that the major sources of brand equity are composed of brand loyalty, brand awareness, perceived quality, and brand associations (Aaker, 1996; Bendixen et al., 2004). Therefore, we employed these four factors to find out the relationship in the internal model. In addition, transition cost (or change cost) has been considered a critical factor that influences purchase intention (Jones et al., 2000; Lee et al., 2001; Yang and Peterson, 2004), related to airline brand equity in particular (Chen and Chang, 2008).

As shown in Figure 1, this study investigates the relationships among the factors of airline brand equity (called the internal model in this study) as well as the relationships between brand equity and purchase intention for air tickets in China (called the external model in this study). The results are expected to provide the airlines in China with marketing strategies and increased sales in the long-term. In addition, this study investigates the customer behavior's differences in different customer groups classified by demographic characteristics such as age, educational level, income, occupation, travelling purpose, and whether the passenger is reimbursed or not. The latter results are expected to provide strategic information to marketers for effective market segmentation in the huge airline market, China.

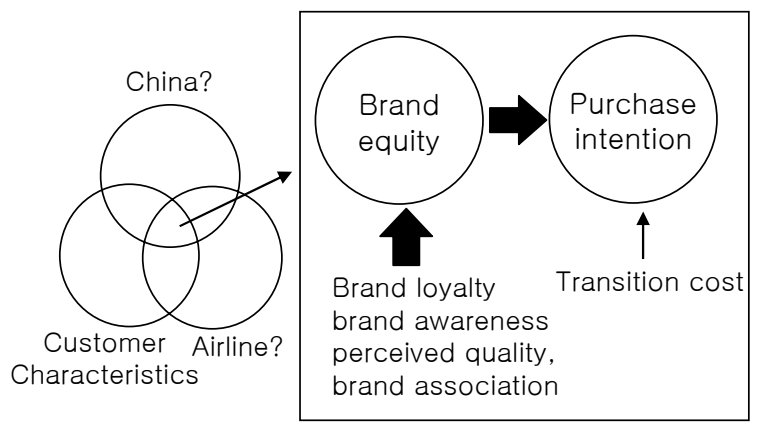

Figure 1. Research framework.

The remainder of this paper is organized as follows: in Section 2, we provide a literature review related to the hypotheses of this study and explain the methodology. Sections 3 and 4 provide results and conclusions, respectively.

\section{LITERATURE REVIEW FOR STRUC- TURAL EQUATION MODELING}

To understand the relationships between the factors that affect the purchase intention of air tickets, structural equation modeling (SEM) was used. From a literature review of previous research on brand, we found direct and indirect factors of brand which affect the purchase intention of goods or services. This study employed certain factors which were considered appropriate to form a structural equation model in the application of the airline brand.

The following subsections introduce the factors that influence the purchase intention of goods or services based on the literatures. Seven research hypotheses based on these factors are then offered.

\subsection{SEM Factors and Hypotheses}

As aforementioned in the introduction part, four major factors of airline's brand equity (brand loyalty, brand awareness, perceived quality, and brand association) and transition cost (Aaker, 1996; Bendixen et al., 2004, Jones et al., 2000; Lee et al., 2001; Yang and Peterson, 2004) were examined in finding the relationships with purchase intention of airline tickets, and seven hypotheses were then developed to explain the relationships as follows.

\subsubsection{Brand equity and purchase intention}

Brand equity has five components: brand loyalty, brand awareness, perceived quality, brand association, and other proprietary brand assets (Aaker, 1991, 1996; Yoo and Donthu, 2001). Brand equity influences the purchase intention of goods (Aaker, 1991, 1996; Yoo and Donthu, 2001). Products' brand equity affects long-term cash flow and purchase intention (Srivastava and Shocker, 1991). In addition to products' brand equity, consumers are willing to pay for premium prices for nonproduct related brands (Keller, 1993). By using the ideas for this study, we assume that brand equity influences purchase intention of airline tickets in China too. Thus, the first hypothesis (H1) for this study is formulated as follows:

$\mathrm{H} 1$ : Brand equity has a positive impact on the purchase intention of air tickets in China.

\subsubsection{Moderating effect of transition cost}

Transition cost is that cost associated with switching the provider from one source to another (Klemperer, 1987; Weiss and Anderson, 1992; Heide and Weiss, 1995). Transition cost influences customer satisfaction, customer loyalty, and/or purchase intention in service industries (Jones et al., 2000; Lee et al., 2001; Yang and Peterson, 2004). Carlsson and Lofgren (2006) investigated the transition barriers in airline ticketing, and claim that when there is a higher transition barrier, there is a higher customer loyalty and higher purchase intention. Likewise, the second hypothesis (H2) is formed as follows:

H2: Transition cost has a positive impact on the purchase intention of air tickets in airlines in China.

\subsubsection{Brand awareness and brand association}

Brand awareness is defined as the ability to learn 
and remember a brand (Keller, 1993). If customers have a higher ability to remember a brand, they tend to have higher knowledge on the image associated with that brand, defined as brand association (Zinnbauer and Bakay, 2004; Villarejo-Ramos and Sanches-Franco, 2005). The brand association becomes stronger when it is based on many experiences or exposures (Aaker, 1991) by which consumers get to remember the brand of products or services easily. Consumers also have an expectation that a product or service has an association influenced by other associations (Bettman et al., 1986; Sujan, 1985), i.e., brand awareness. From these ideas, we can say that brand association might be influenced by brand awareness in the airline industry in China. Therefore, the third hypothesis (H3) is formulated as follows:

H3: Brand awareness has a positive impact on brand association in airline ticketing in China.

\subsubsection{Brand awareness and perceived quality}

Perceived quality is the customer's perception of the product or service quality compared to the rivalry offering in respect to its intended purpose, and that perception is regarded as the most important part of brand equity (Zeithaml, 1988; Aaker, 1996; Yoo and Donthu, 2001; Panchal et al., 2012; Severi and Ling, 2013). Brand reputation is an indirect indicator of product quality (Allison and Uhl, 1964; Freidman and Dipple 1978), and therefore, we can assume that perceived quality of products or services is influenced by brand reputation which links directly to brand awareness. That is, high brand awareness reflects the familiarity with products or services, thus increasing the perceived quality. Based on the latter idea, the fourth hypothesis (H4) is formed as follows:

H4: Brand awareness has a positive impact on perceived quality in airline ticketing in China.

\subsubsection{Perceived quality and brand association}

Consumers associate a product's brand image when deriving perceptions of the product (Richardson et al., 1994). Perceived quality is affected by brand image (Jacoby et al., 1971), and brand image or association is served as a reference for the quality of products or services (Shimp and Bearden, 1982). Perceived quality has a positive and key impact on brand association (Park et al., 2004; Aydin and Ozer, 2005). That is, consumers expect higher perceived quality with products or services having higher brand association. Based on these ideas, the fifth hypothesis (H5) is formed as follows:

H5: Perceived quality has a positive impact on brand association in airline ticketing in China.

\subsubsection{Perceived quality and brand loyalty}

Customer loyalty refers to the customer behavior related to the product, the service or the company (An- dreassen and Lindestad, 1998). Likewise, Brand loyalty is a devoted mindset toward a brand that leads to constant purchasing of the brand over time (Aaker, 1991). A service company's image (which can be referred to as a brand) functions as a filter in the perception of quality, value, and satisfaction when consumers choose where to purchase services (Andreassen and Lindestad, 1998). Perceived service quality is needed for forming customer loyalty (Aydin and Ozer, 2005). In line with their idea, Jones et al. (2002) point out that the quality perceived from products or services has a positive impact on recommendations for those products or services. We, therefore, assume that recommending products or services works as a part of brand loyalty. Based on this idea, the sixth hypothesis (H6) is formulated as follows:

H6: Perceived quality has a positive impact on brand loyalty in airline ticketing in China.

\subsubsection{Brand association and brand loyalty}

Customers having more brand association would have more brand loyalty (Yoo et al., 2000; Atilgan et al., 2005). Zinnbauer and Bakay (2004) also found that brand association has a positive impact on brand loyalty. In relation to airlines in particular, Park et al., (2004) point out that when customers have a positive brand association with an airline, they will be more likely to retake this airline brand or recommend this brand to others. We, therefore, included their idea in the last hypothesis (H7) as follows:

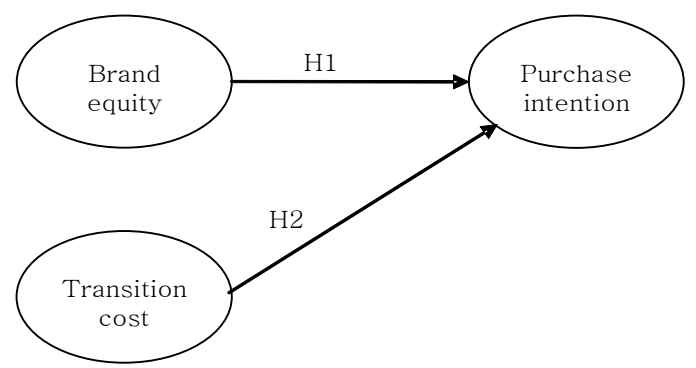

(a)

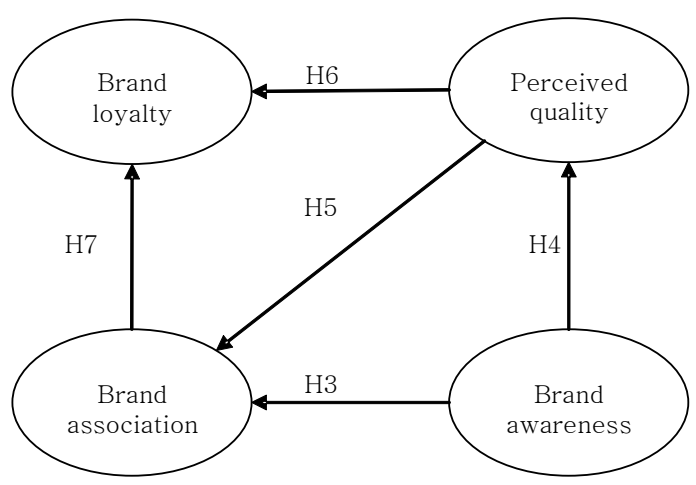

(b)

Figure 2. Seven hypotheses for structural equation modeling. (a) The external model for brand equity, (b) the internal model for brand equity. 
H7: Brand association has a positive impact on brand loyalty in airline ticketing in China.

In Figure 2, we constructed 7 hypotheses for 2 separate structural equation models: the external model and the internal model. The external model is based on hypotheses for brand equity, transition cost, and purchase intention to understand the influence of brand equity on purchase intention. The internal model is based on relationships among the four main determinants of brand equity (Aaker, 1991, 1996; Yoo and Donthu, 2001). Both models are depicted below.

\subsection{Methodology}

Table 1. Participant compositions for the survey

\begin{tabular}{|c|c|}
\hline Questionnaire & No. of participant \\
\hline \multicolumn{2}{|l|}{ Age } \\
\hline$<25$ & 42 \\
\hline $25 \sim 30$ & 41 \\
\hline $31 \sim 40$ & 51 \\
\hline $41 \sim 50$ & 40 \\
\hline$>51$ & 14 \\
\hline \multicolumn{2}{|l|}{ Education } \\
\hline Below college & 54 \\
\hline Undergraduate & 90 \\
\hline Master & 31 \\
\hline $\mathrm{PhD}$ & 13 \\
\hline \multicolumn{2}{|l|}{ Income } \\
\hline$<3000 \mathrm{RMB}$ & 65 \\
\hline $3000 \sim 6000 \mathrm{RMB}$ & 73 \\
\hline $6001 \sim 9000 \mathrm{RMB}$ & 31 \\
\hline$>9000 \mathrm{RMB}$ & 19 \\
\hline \multicolumn{2}{|l|}{ Occupation } \\
\hline Student & 37 \\
\hline Government & 61 \\
\hline Business & 42 \\
\hline Industry & 29 \\
\hline Retired/others & 19 \\
\hline \multicolumn{2}{|l|}{ Purpose } \\
\hline Business & 72 \\
\hline Travel & 60 \\
\hline Others & 56 \\
\hline \multicolumn{2}{|l|}{ Reimbursement } \\
\hline Yes & 59 \\
\hline No & 108 \\
\hline No response & 21 \\
\hline
\end{tabular}

A questionnaire was developed for the structural equation modeling. We primarily referred to Chen's questionnaire (Chen, 2008). The questionnaire offered two to six questions for each factor based on the literature review (Aaker, 1991, 1996; Chen, 2008; Chen and Chang, 2008; Rossiter and Percy, 1997; Lassar et al., 1995; Keller, 1993; Park et al., 2004; Yoo et al., 2000) and serving as measurable variables to measure the latent variables in the structural equation models. The survey was conducted in May, 2010 at Beijing International Airport and Xiamen Gaoqi International Airport. A total of 220 questionnaires were collected. Of 220 participants, 188 were valid. Table 1 summarizes the participant characteristics by age, educational level, income, occupation, travelling purpose, and whether he or she was reimbursed or not. This data were then used for further analysis to investigate differences among the participant groups.

\section{RESULTS}

Cronbach's Alpha Test was initially conducted to check whether the questionnaire had internal consistency. All coefficients for seven question categories were over 0.7 , revealing the internal consistency of the questionnaire. AMOS was then used to understand the relationships within the models.

\subsection{Effects for Determinants of Brand Equity}

As shown in Table 2, the model proved to be reasonable. All indices indicating model fitness fell within the criteria. The maximum-likelihood estimation procedures were then used to examine relationships for the determinants of brand equity (brand awareness, perceived quality, brand association, and brand equity).

Table 2. Model fit indices for the determinants of brand equity

\begin{tabular}{lcc}
\hline \multicolumn{1}{c}{ Index } & Result & Criteria \\
\hline RMSEA & 0.074 & $<0.08$ \\
GFI & 0.879 & $>0.8$ \\
AGFI & 0.833 & $>0.8$ \\
CFI & 0.920 & $>0.9$ \\
PGFI & 0.638 & $>0.5$ \\
PNFI & 0.699 & $>0.5$ \\
\hline
\end{tabular}

Figure 3 shows the relationships for the determinants of brand equity, and Table 3 shows their direct and indirect effects on the model. Brand awareness and brand association, for example, in the table, brand awareness had a 0.667 positive effect on brand association, with 0.527 direct effect and 0.140 indirect effect calculated by 0.562 (brand awareness to perceived quality) multiplied by 0.250 (perceived quality to brand association) as shown below. 


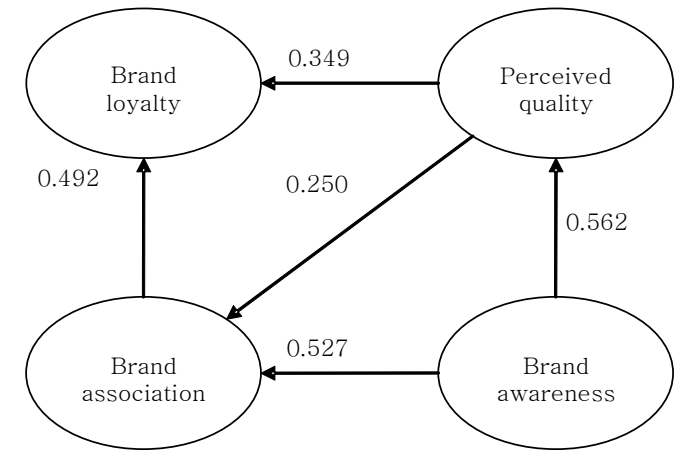

Figure 3. Relationships for the determinants of brand equity.

In sum, hypotheses (H3 to H7) were supported for the internal structural equation model. Brand awareness had significantly positive effects on both perceived quality and brand association, supporting $\mathrm{H} 3$ and H4. Perceived quality had significantly positive effects on both brand association and brand loyalty, supporting $\mathrm{H} 5$ and H6. Furthermore, brand association on brand loyalty was also significant, supporting $\mathrm{H} 7$.

Table 3. Hypothesis tests of determinants for the brand equity model

\begin{tabular}{ccccc}
\hline Hypotheses & $\begin{array}{c}\text { Direct } \\
\text { effect }\end{array}$ & $\begin{array}{c}\text { Indirect } \\
\text { effect }\end{array}$ & $\begin{array}{c}\text { Total } \\
\text { effect }\end{array}$ & Pass \\
\hline $\begin{array}{c}\text { Brand awareness } \\
\rightarrow \text { Brand association }\end{array}$ & 0.527 & 0.140 & 0.667 & Yes \\
$\begin{array}{c}\text { Brand awareness } \\
\rightarrow \text { Perceived quality }\end{array}$ & 0.562 & - & 0.562 & Yes \\
$\begin{array}{c}\text { Perceived quality } \\
\rightarrow \text { Brand association }\end{array}$ & 0.250 & - & 0.250 & Yes \\
$\begin{array}{c}\text { Perceived quality } \\
\rightarrow \text { Brand loyalty }\end{array}$ & 0.349 & 0.123 & 0.472 & Yes \\
$\begin{array}{c}\text { Brand association } \\
\rightarrow \text { Brand loyalty }\end{array}$ & 0.492 & - & 0.492 & Yes \\
\hline
\end{tabular}

\subsection{Effects for Factors in the External Model}

As shown in Table 4, all indices indicating model fitness fell within the criteria. Maximum-likelihood estimation procedures were used to examine the relationships for brand equity, transition cost and purchase intention.

Table 4. Model fit indices the external model

\begin{tabular}{lcc}
\hline \multicolumn{1}{c}{ Index } & Result & Criteria \\
\hline RMSEA & 0.067 & $<0.08$ \\
GFI & 0.951 & $>0.8$ \\
AGFI & 0.908 & $>0.8$ \\
CFI & 0.972 & $>0.9$ \\
PGFI & 0.507 & $>0.5$ \\
PNFI & 0.628 & $>0.5$ \\
\hline
\end{tabular}

Figure 4 shows the relationships among factors in the external model, and Table 5 shows their direct and indirect effects on the model. As shown in Table 5, two hypothesized relationships were supported in the estimated structural model. Brand equity had a significantly positive effect on purchase intention, supporting H1. Transition cost had a significantly positive effect on brand equity and, therefore, had a positively indirect effect on purchase intention, supporting $\mathrm{H} 2$. The direct effect of brand equity on purchase intention was 0.919 . Meanwhile, the effect of transition cost on purchase intention, 0.233 was an indirect effect mediated by brand equity.

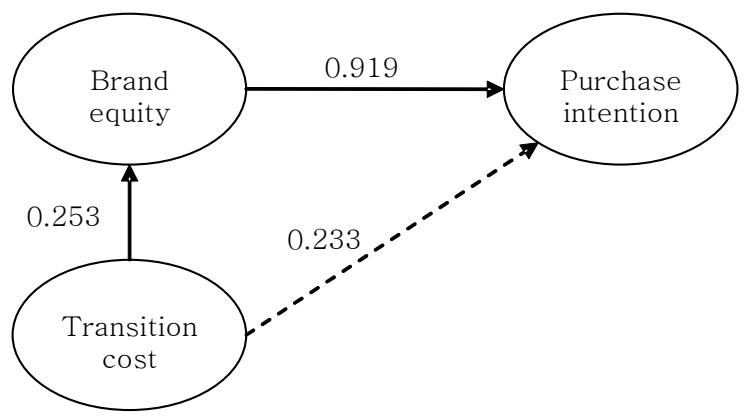

Figure 4. Relationships for factors in the external model.

Table 5. Hypothesis tests of factors in the external model

\begin{tabular}{ccccc}
\hline Hypotheses & $\begin{array}{c}\text { Direct } \\
\text { Effect }\end{array}$ & $\begin{array}{c}\text { Indirect } \\
\text { effect }\end{array}$ & $\begin{array}{c}\text { Total } \\
\text { effect }\end{array}$ & Pass \\
\hline $\begin{array}{c}\text { Transition cost } \\
\rightarrow \text { Purchase intention }\end{array}$ & - & 0.233 & 0.233 & Yes \\
$\begin{array}{c}\text { Brand equity } \\
\rightarrow \text { Purchase intention }\end{array}$ & 0.919 & - & 0.919 & Yes \\
\hline
\end{tabular}

\subsection{Differences by Demographic Groups}

While understanding the importance of brand equity on purchase intention, airline companies need to translate it into marketing strategies on specific target population. We additionally analyzed the data for several participant groups classified by demographics for any significant differences. Some interesting information was obtained:

- Participants between age 30 to 40 were more brand sensitive.

- Participants with salary over 6000 RMB paid more attention to brand equity.

- Female participants highly rated brand awareness and brand association, and brand equity, but there were no significant differences for brand loyalty, perceived quality, transition cost, and purchase intention between female and male participants. That is, females tended to pay more attention to the brand, but their interests in the brand did not necessarily lead to brand loyalty and purchase intention.

- Married participants showed more interest in brand, and they were willing to pay more transition cost for their preferred brand. 
- Government servants and businessmen gave higher scores on brand awareness, brand association, brand loyalty, brand equity, and purchase intention. The latter result indicates that people in this group are more likely to convert brand preferences to purchase intention. In this respect, airline brand marketing could be targeted to this group of customers.

- Both membership travelers and reimbursed travelers gave higher scores on brand equity and purchase intention.

- Education, flying experience, cabin class, and travel purpose did not produce any significant differences.

In summary, airline brand marketing can be more effectively applied to the following specific customer groups: Passengers age 40 to 50, married passengers, government servants, and businessmen. Membership marketing is also a good way to improve brand equity and increase purchase intention in the long term.

\section{CONCLUSIONS AND DISCUSSION}

With the rapid economic growth of China, the importance of research on the relationship of customer behavior and brand in China has increased. Most of the research on the airline service has focused on service quality, whereas the effect of airline brands in China has been neglected. However, in the rapidly growing Chinese airline market, it is important to understand the influence of airline brands on the purchase intention for air tickets. This study offers two structural equation models: the internal model and the external model. The internal model is based on the relationships among brand loyalty, brand association, brand awareness, and perceived quality, which are the main components of brand equity (Yoo and Donthu, 2001). The external model represents relationships among brand equity, transition cost, and purchase intention. These relationships in the structural equation models have not been studied for Chinese airline brands yet although the brand is considered one of the most important factors (brand, safety, departure time, service, price, punctuality, plane type, and frequent flyer) influencing passengers' decision for airline choice (defined by Civil Aviation Administration of China).

In the internal model, we offer the following findings: 1) Brand awareness positively influences brand association; 2) Brand awareness positively influences perceived quality; 3) Perceived quality positively influences brand association; 4) Perceived quality positively influences brand loyalty; and 5) Brand association positively influences brand loyalty. In this model, brand awareness is regarded as the most essential factor for improving brand equity. That is, improving brand awareness directly or indirectly influences brand association, brand quality and brand loyalty and increases the brand equity of airlines.
In the external model, we had the following findings: 1) Brand equity directly influences purchase intention; 2) transition cost directly influences brand equity; and 3) transition cost indirectly influences purchase intention. These results from the external model are consistent with Chen and Chang (2008)'s research. That is, we conclude that the airline brand equity directly influences the increase of the purchase intention of airline ticket for either Chinese or Taiwanese passengers. Considering GDP per capita of Taiwan is more than three times of China's (by IMF), other factors such as culture could be more plausible to explain this similar tendency for both countries toward airline brand as Monga and John (2007) pointed out. In addition, apart from Chen and Chang (2008)'s research, this study also provides strategic ideas for marketers to increase airline brand equity for Chinese airlines from the internal model of the brand equity.

In conclusion, the combined the results from both models indicate that brand equity is the critical factor for increasing the purchase intention of air tickets. However, because brand equity is also directly or indirectly influenced by other factors, specifically brand loyalty, brand association, brand awareness, perceived quality, and transition cost, marketing strategies that improve the brand awareness and lower the transition cost could be efficient ways to increase the purchase intention of air tickets. For example, promoting frequent passenger plans could be an efficient way to improve brand loyalty, brand association, brand awareness and transition cost, all of which can help form a greater brand equity.

In addition, marketing strategies that focus on certain target customer groups could increase airline brand equity efficiently. High income customers, married customers, membership passengers, reimbursed travelers, government servants, and businessmen are more brand sensitive, and therefore, brand promotion to these people could be an efficient way to attract more airline passengers in the Chinese market. Therefore, airline companies need to allocate more marketing resources for brand to these groups of customers to make their brand promotion activities more efficient.

Although this study provides certain useful marketing guidelines for airlines in China, it does have some limitations. The study should be interpreted carefully because the data analyzed was collected only in Beijing and Xiamen. Considering that China has diverse ethnic groups, economic variations, and regional cultural differences due to its large population, all of which influence customer behavior, further study is needed to cover all the broad ranges of the population to confirm and generalize these results. In addition, this study did not show the relationship between the internal model and the external model clearly because the original structural equation models were constructed separately. Also some further research is necessary to explain the reasons of the cause-effect relationships and some the cultural meanings in Chinese locale. 


\section{REFERENCES}

Aaker, D. A. (1991), Managing Brand Equity: Capitalizing on the Value of a Brand Name, Free Press, New York, NY.

Aaker, D. A. (1996), Measuring brand equity across products and markets, California Management Review, 38(3), 102-120.

Aksoy, S., Atilgan, E., and Akinci, S. (2003), Airline services marketing by domestic and foreign firms: differences from the customers' viewpoint, Journal of Air Transport Management, 9(6), 343-351.

Atilgan, E., Aksoy, S., and Akinci, S. (2005), Determinants of the brand equity: a verification approach in the beverage industry in Turkey, Marketing Intelligence and Planning, 23(3), 237-248.

Allison, R. I. and Uhl, K. P. (1964), Brand identification and perception, Journal of Marketing Research, $\mathbf{1}$, 36-39.

Andreassen, T. W. and Lindestad, B. (1998), Customer loyalty and complex services: the impact of corporate image on quality, customer satisfaction and loyalty for customers with varying degrees of service expertise, International Journal of Service Industry Management, 9(1), 7-23.

Aydin, S. and Ozer, G. (2005), The analysis of antecedents of customer loyalty in the Turkish mobile telecommunication market, European Journal of Marketing, 39(7-8), 910-925.

Bendixen, M., Bukasa, K. A., and Abratt, R. (2004), Brand equity in the business-to-business market, Industrial Marketing Management, 33(5), 371-380.

Bettman, J. R., John D. R., and Scott, C. A. (1986), Covariation assessment by consumers, Journal of Consumer Research, 13(3), 316-326.

Carlsson, F. and Lofgren, A. (2006), Airline choice, switching costs and frequent flyer programmes, $A p$ plied Economics, 38(13), 1469-1475.

Chen, C. F. (2008), Investigating structural relationships between service quality, perceived value, satisfaction, and behavioral intentions for air participants: evidence from Taiwan, Transportation Research Part A: Policy and Practice, 42(4), 709-717.

Chen, C. F. and Chang, Y. Y. (2008), Airline brand equity, brand preference, and purchase intentions: the moderating effects of switching costs, Journal of Air Transport Management, 14(1), 40-42.

Freidman, H. H. and Dipple, W. S. Jr. (1978), The effect of masculine and feminine brand names on the perceived taste of a cigarette, Decision Sciences, 9(3), 467-471.

Heide, J. B. and Weiss, A. M. (1995), Vendor consideration and switching behavior for buyers in hightechnology markets, Journal of Marketing, 59(3), $30-43$.
Hu, S. J., Jou, S. Y., and Liu, Y. H. (2009), Structural equation model for brand image measurement of jeans, Proceedings of the 9th International Conference on Hybrid Intelligent Systems, Shenyang, China, 89-94.

Hwang, J. and Kandampully, J. (2012), The role of emotional aspects in younger consumer-brand relationships, Journal of Product and Brand Management, 21(2), 98-108.

Jacoby, J., Olson, J. C., and Haddock, R. A. (1971), Price, brand name, and product composition characteristics as determinants of perceived quality, Journal of Applied Psychology, 55(6), 570-579.

Jones, M. A., Mothersbaugh, D. L., and Beatty, S. E. (2000), Switching barriers and repurchase intentions in services, Journal of Retailing, 76(2), 259-274.

Jones, M. A., Mothersbaugh, D. L., and Beatty, S. E. (2002), Why customers stay: measuring the underlying dimensions of services switching costs and managing their differential strategic outcomes, Journal of Business Research, 55(6), 441-450.

Keller, K. L. (1993), Conceptualizing, measuring, and managing customer-based brand equity, Journal of Marketing, 57(1), 1-22.

Keller, L. K. (2012), Strategic Brand Management (4th ed.), Prentice Hall, Upper Saddle River, NJ.

Kim. W. G. and Kim H. B. (2004), Measuring customerbased restaurant brand equity: investigating the relationship between brand equity and firm's performance, Cornell Hotel and Restaurant Administration Quarterly, 45(2), 115-131.

Klemperer, P. (1987), The competitiveness of markets with switching costs, RAND Journal of Economics, 18(1), 138-150.

Lassar, W., B. Mittal, and Sharma, A. (1995), Measuring customer-based brand equity, Journal of Consumer Marketing, 12(4), 11-19.

Lee, J., Lee, J., and Feick, L. (2001), The impact of switching costs on the customer satisfaction-loyalty link: mobile phone service in France, Journal of Services Marketing, 15(1), 35-48.

Monga, A. B. and John, D. R. (2007), Cultural differences in brand extension evaluation: the influence of analytic versus holistic thinking, Journal of Consumer Research, 33(4), 529-536.

Ostrowski, P. L., O’Brien, T. V., and Gordon, G. L. (1993), Service quality and customer loyalty in the commercial airline industry, Journal of Travel Research, 32(2), 16-24.

Panchal, S. K., Khan, B. M., and Ramesh. S. (2012), Importance of 'brand loyalty, brand awareness and perceived quality parameters' in building brand equity in the Indian pharmaceutical industry, Journal of Medical Marketing, 12(2), 81-92.

Pappu, R., Quester, P. G., and Cooksey, R. W. (2005), Consumer-based brand equity: improving the mea- 
surement: empirical evidence. Journal of Product and Brand Management, 14(3), 143-154.

Park, J. W., Robertson, R., and Wu, C. L. (2004), The effect of airline service quality on participants' behavioural intentions: a Korean case study, Journal of Air Transport Management, 10(6), 435-439.

Richardson, P. S., Dick, A. S., and Jain, A. K. (1994), Extrinsic and intrinsic cue effects on perceptions of store brand quality, Journal of Marketing, 58(4), 28-36.

Rossiter, J. and L. Percy (1997), Advertising Communications and Promotion Management, McGraw-Hill Companies.

Severi, E. and Ling, K. C. (2013), The mediating effects of brand association, brand loyalty, brand Image and perceived quality on brand equity, Asian Social Science, 9(3), 125-137.

Shimp, T. A. and Bearden, W. O. (1982), Warranty and other extrinsic are effects on consumer's risk perceptions, Journal of Consumer Research, 9(1), 3846.

Sujan, M. (1985), Consumer knowledge: effect on evaluation strategies mediating consumer judgment, Journal of Consumer Research, 12(1), 31-46.

Srivastava, R. K. and Shocker A. D. (1991), Brand equity: a perspective on its meaning and measurement. Technical Report No. 91-124, Marketing Science Institute, Cambridge, MA.

Sultan, F. and Simpson, M. C. (2000), International service variants: airline passenger expectations and perceptions of service quality, Journal of Services Marketing, 14(2/3), 188-216.
Tolba, A. H. and Hassan, S. S. (2009), Linking customer based brand equity with brand market performance: a managerial approach, Journal of Product and Brand Management, 18(5), 356-366.

Villarejo-Ramos, A. F. and Sanchez-Franco, M. J. (2005), The impact of marketing communication and price promotion on brand equity, Journal of Brand Management, 12(6), 431-444

Weiss, A. M. and Anderson, E. (1992), Converting from independent to employee salesforces: the role of perceived switching costs, Journal of Marketing Research, 29(1), 101-115.

Yang, Z. and Peterson, R. T. (2004), Customer perceived value, satisfaction, and loyalty: the role of switching costs, Psychology and Marketing, 21(10), 799-822.

Yoo, B. and Donthu, N. (2001), Developing and validating a multidimensional consumer-based brand equity scale, Journal of Business Research, 52(1), 114.

Yoo, B., Donthu, N., and Lee, S. (2000), An examination of selected marketing mix elements and brand equity, Journal of the Academy of Marketing Science, 28(2), 195-211.

Zeithaml, V. A. (1988), Consumer perceptions of price, quality, and value: a means-end model and synthesis of evidence, The Journal of Marketing, 52(3), 222.

Zinnbauer, M. A. and Bakay, Z. (2004), Modeling brand equity in a modern business context, SAM/IFSAM VII World Congress, 5-7 July, 2004, Göteborg, Sweden. 